\title{
Current concepts for tissue transplant services for developing countries
}

\author{
Francisco J. Verdugo-Avello • Jacek K. Wychowaniec (iD) - Matias Jimenez • \\ Silvana Jimenez $\cdot$ Soraya Gutierrez
}

Received: 24 July 2020/Accepted: 8 December 2020/Published online: 4 January 2021

(C) The Author(s), under exclusive licence to Springer Nature B.V. part of Springer Nature 2021

\begin{abstract}
The transplantation of tissues can save lives and re-establish vital functions, where no alternatives of comparable effectiveness exist. This has led to establishment of tissue transplantation as a successful practice worldwide; however, a great variability between countries remains in terms of donation levels, safety, quality of grafts and their efficacy. Tissue transplantation requires coordination of different agencies involved in the implementation of procurement, processing, storage and distribution of tissues and cells from different hospital units that perform surgical procedures with graft-type input requirements. This biomaterial-like requirement has led to the constant development of the area and today these graft products of human origin can be the starting point for new and more advanced biotechnological products. For long-term sustainability and successful transplantation units, a process management comparable to the pharmaceutical industry in terms of quality
\end{abstract}

F. J. Verdugo-Avello · M. Jimenez .

S. Jimenez $\cdot$ S. Gutierrez

Facultad de Ciencias Biológicas, Universidad de

Concepción, Concepción, Chile

F. J. Verdugo-Avello $(\bowtie) \cdot$ M. Jimenez $\cdot$ S. Jimenez

LiveMatrix Biotech, Concepción, Chile

e-mail: fverdugo@livematrix.cl

J. K. Wychowaniec

School of Chemistry, University College Dublin,

Belfield, Dublin 4, Ireland management systems must be established to produce safe and high-quality human-derived products. This review aims to update the current concepts of tissue transplant services for its application for developing countries using the current Chilean scenario as a case study. We summarize our findings proposing a set of guidelines/actions that should be followed to ensure smooth tissue transplant services implementations with high efficiency and safe use.

Keywords Tissue transplant · Human-derived tissue products - Quality management system - Healthcare innovation $\cdot$ Health sustainable development

\begin{tabular}{|c|c|}
\hline \multicolumn{2}{|c|}{ Abbreviations } \\
\hline & $\begin{array}{l}\text { Latin American Association of Tissue } \\
\text { Banks }\end{array}$ \\
\hline ATMPs & Advanced therapy medicinal products \\
\hline $\mathrm{CD}$ & Cadaveric donor \\
\hline CNPT & National Transplant Coordination \\
\hline DBD & Deceased donor with brain death \\
\hline EATCB & $\begin{array}{l}\text { European Association of Tissue and Cell } \\
\text { Banks }\end{array}$ \\
\hline FONASA & Fondo Nacional de Salud \\
\hline GMP & Good manufacturing practices \\
\hline IAEA & International Atomic Energy Agency \\
\hline $\mathrm{ICH}$ & The International Council for \\
\hline & Harmonization of Technical \\
\hline & $\begin{array}{l}\text { Requirements for Pharmaceuticals for } \\
\text { Human Use }\end{array}$ \\
\hline
\end{tabular}




$\begin{array}{ll}\text { ISP } & \text { Institute of Public Health } \\ \text { kGy } & \text { Kilograys } \\ \text { LD } & \text { Living donor } \\ \text { MINSAL } & \text { Ministry of Health } \\ \text { SAL } & \text { Level of sterility assurance } \\ \text { SIDOT } & \text { Integrated Donation and Transplant } \\ & \text { System } \\ \text { SNSS } & \text { National Health Services System } \\ \text { UATs } & \text { Transitory Storage Units } \\ \text { WHO } & \text { World Health Organization }\end{array}$

\section{Introduction}

The current development of cell and tissue transplantation is contributing to a new era of healthcare services (Ashammakhi et al. 2019). They represent a specific class of products fundamental to a human health, and can be the raw material for the development of more advanced biotechnological products (Fratzl 2007). Currently, these biological medicinal products have no synthetic equivalents in cost-effectiveness for tissue repair and reconstruction (Zorzi and Miranda 2012). The cell and tissue donation should always be based on a clinical evaluation, considering the risks versus the benefits and taking into account all available therapies for treatment selection (World Health Organization 2006). Health service professionals involved in transplantation must take all the necessary measures during the evaluation of the donor in order to procure, store, process and distribute cells and tissues within levels of safety according to local regulations (World Health Organization 2010). In addition, any institution involved in this process must implement a comprehensive quality management system, which must be carried out, monitored and constantly improved to ensure best safe practice methods and availability of donations for most needed therapies and research development (European Directorate for the Quality of Medicines \& Healthcare (EDQM) 2019).

Using legislations and benchmarks similar to pharmaceutical industry standards, biotechnological platforms producing more complex and effective grafts can be achieved. Various human tissue-derived products are required on a daily basis, as in the case of dermal allografts (e.g. human grafts from different persons), in various forms according to the surgical requirements (Calota et al. 2012). Likewise, bone allograft processing has resulted in multiple products for orthopaedic (Campana et al. 2014; Pierannunzi and Zagra 2016), dental (Lobb et al. 2019; Kao and Scott 2007), maxillofacial (Allegrini et al. 2008; Nkenke and Stelzle 2009), and neurosurgery (Chau et al. 2014; Canzi et al. 2018) reconstruction fields. The allografts can be free of cellular components and even free of calcium (Drosos et al. 2015) to improve its host's acceptance and tissue repair. They can be dispensed in blocks, sheets and even in the form of an injectable paste (Acarturk and Hollinger 2006). Advances in processing techniques and the development of advanced therapies have led to a new generation of processing techniques, such as the "decellularization", a process that can prevent immune reactions in the recipient (Badylak et al. 2011; Crapo et al. 2011), acting as a "scaffold", which can be combined with various other cells by the principles of tissue engineering. However, to achieve successful translation of these materials, good manufacturing practices with concepts of quality management, validation and risk management are required in parallel to the clinical transplantation process (European Directorate for the Quality of Medicines \& Healthcare (EDQM) 2019).

For developing countries, it is critical to improve National production of tissue-derived products for essential healthcare activities. Importing grafts from elsewhere is associated with high costs (Benninger et al. 2014). Several surgical therapies solely depend on the use of the grafts as most effective, and thus selfsustained tissue transplant services are necessary. Furthermore, many situations such as pandemics lead to a rapid health system saturation and collapse (e.g. due the SARS-CoV-2), therefore indicating the necessity of sustainable measures in less richer economies. This is not only needed for the local health system improvements, but also to achieve global sustainability during a sanitary crisis. Hence, in the following review of the literature, we aim to update the current concepts of tissue transplantation. In particular, we put special emphasis on the Chilean public healthcare system point-of-view, as an example of a developing country. We highlight the following: (i) regulatory issues and bioethics, (ii) tissue procurement and manufacturing, (iii) bioprocessing with specific 
regulatory requirements, and finally (iv) quality management system, validation and risk assessment.

\section{Regulatory issues}

The World Health Organization (WHO) states that the local health authorities are responsible for guaranteeing the promotion of donation, storage and human application of tissues and cells, monitoring patients' safety and remaining publically transparent with respect to the health-related statistics and treatments (Competent Authorities on Substances of Human Origin Expert Group (CASoHO E0 1718; World Health Organization 2020). Local authorities can be guided by tissue banking-scientific associations for the co-development of the different regulations according to the country of origin, such as the "Directive 2004/23/EC", 2006/17/EC and 2006/86/EC of the European Union, ${ }^{1}$ the guide "Human Tissue Act" of the United Kingdom (Human Tissue 2020; Human Tissue Authority 2020), and "Human Cells, Tissues, and Cellular and Tissue-based Products" (Code of Federal Regulations Title 21 2020) of the United States Federal Drug Administration. In Chile, this area is under law normative, Ley $\mathrm{N}^{\circ} 19,451$ about "Organ Donation and Transplantation (updating Decree No. 240 of the ninth book of the health code, year 1983)" (Ley $\mathrm{N}^{\circ}$ 1996) which was published in 1996.

Chile has been employed to present a case study from an exemplar developing country. The Chilean law "Ley $\mathrm{N}^{\circ} 19.451$ " is relatively new compared to the European Union (EU) and was established in the year 1996 alongside with the "National Transplant Coordination (i.e. Coordinación Nacional de Procuramiento y Trasplantes de Órganos y Tejidos) (CNPT) of the "Ministry of Health (MINSAL)", which aims to implement a National policy on the transplantation rules, objectives and principles, applicable to the entire network-public and private-of the Chilean "National Health Services System (SNSS)". Although, this law deals mainly with aspects related

\footnotetext{
${ }^{1}$ Directive 2006/86/EC as regards traceability requirements, notification of serious adverse reactions and events and certain technical requirements for the coding, processing, preservation, storage and distribution of human tissues and cells. https://eurlex.europa.eu/LexUriServ/LexUriServ.do?uri=OJ:L:2006:294: 0032:0050:EN:PDF, Accessed on May 2020.
}

to organ donation and it was later complemented with additional regulations (Ley $\mathrm{N}^{\circ}$ 1996; Decreto $\mathrm{N}^{\circ}$ 2013), it does not actually address tissue transplantation. Some later legislative progress was made with the publication of technical standards $\mathrm{N}^{\circ} 163$ for the procurement, preservation and implantation of corneas, in the year 2014 (Decreto Exento 2016) and with the technical standard $\mathrm{N}^{\circ} 200$, for Procurement, Preservation and Implant of Tissues, in the year 2018 (Ministerio de Salud 2018). The case study of establishing these regulations was a clear driveforward for promoting the development of clinical management in tissue science nationwide (Cuarto Informe y final FIC 2013; Hospital Las Higueras implementó el primer Banco de Hueso de la Región del Biobío 2018) and was key to achieve a standardized supervision that allows traceability and quality assurance of transplanted tissues during the procurement, selection and sterility process (Ministerio de Salud 2018). As these regulations are fairly recent when compared to developed countries, it will be necessary to promote further public health strategic measures in order to reach the product quality that well-known global graft tissue banks have.

Several bioethics challenges can rise with the establishment of transplantation laws and norms in order to respect the bioethics principles (Beauchamp and Childress 2001), such as gratuity (Council of Europe 2018) as matter of justice, informed consent as part of autonomy, confidentiality has repercussions in the principles of autonomy and no maleficence and finally the quality of tissue that has direct implications in no malificency (Erk 2012; Report from the Nuffield Council on Bioethics 2020). ${ }^{2}$ We summarised the main four sub-categories in Table 1, stating the considerations that need to be taken into account for tissue transplant services before any human-derived manufacturing can occur.

\footnotetext{
$\overline{2}$ Additional Protocol to the Convention on Human Rights and Biomedicine concerning Transplantation of Organs and Tissues of Human Origin. ETS 186-Human Rights and Biomedicine (Additional Protocol), Strasbourg, 24.I.2002. https://rm.coe.int/CoERMPublicCommonSearchServices/ DisplayDCTMContent?documentId=0900001680081562. Visited on May 2020.
} 
Table 1 Main bioethics challenges to be addressed and their implications for developing countries

\begin{tabular}{|c|c|c|}
\hline $\begin{array}{l}\text { Bioethics } \\
\text { challenges }\end{array}$ & Tissue transplant considerations & References \\
\hline Gratuity & $\begin{array}{l}\text { The "Oviedo Convention" refers to the fact that the human body and } \\
\text { its parts should not generate any financial gains. For example in } \\
\text { Chile, the impossibility of receiving compensation for the donation } \\
\text { of human tissues is established under law, as the donation is always } \\
\text { voluntary and free of charge. "Altruistic" donations aim to promote } \\
\text { donation and eliminate disincentives that affect donation, with } \\
\text { compensation, that could be described as covering expenses in the } \\
\text { procurement and processing of a donated human tissue as matter of } \\
\text { health justice }\end{array}$ & $\begin{array}{l}\text { Council of Europe (2018), Erk (2012), } \\
\text { Report from the Nuffield Council on } \\
\text { Bioethics (2020) }\end{array}$ \\
\hline Informed consent & $\begin{array}{l}\text { This step has direct implications in the bioethics principle of autonomy } \\
\text { and it implies that the donor has understood all the information about } \\
\text { the use that will be given to the tissue bank and that it grants its } \\
\text { approval expressly, freely, consciously and disinterestedly, } \\
\text { understanding that the donation corresponds to a free and voluntary } \\
\text { act to contribute to the common good. In deceased donors in Chile, } \\
\text { this step is taken and is authorized by the potential donor's relatives } \\
\text { under the "request for last will testimony" }\end{array}$ & $\begin{array}{l}\text { Beauchamp and Childress (2001), See } \\
\text { Footnote } 2\end{array}$ \\
\hline Confidentiality & $\begin{array}{l}\text { Refers to the fact that in no case the information can be disseminated to } \\
\text { identify the donor and recipient of human tissue and vice versa. In } \\
\text { Chile, to process donor and recipients information in confidentiality, } \\
\text { the data is transferred to codes administered by the "Integrated } \\
\text { Donation and Transplant System" (SIDOT) software from MINSAL }\end{array}$ & $\begin{array}{l}\text { Ministerio de Salud (2018), See } \\
\text { Footnote } 2\end{array}$ \\
\hline $\begin{array}{l}\text { Quality, safety } \\
\text { and } \\
\text { effectiveness }\end{array}$ & $\begin{array}{l}\text { Refers to how the tissues can be implanted in multi-receptors and } \\
\text { implies that the generation of any batch of tissue should not generate } \\
\text { a risk of multiple infections and the tissues (bioethics principle of no- } \\
\text { maleficence), in this case grafts, are safe, effective and with a } \\
\text { "guarantee of quality" or planned, systematic and documented } \\
\text { actions, necessary to provide safety to the receiving patient }\end{array}$ & $\begin{array}{l}\text { Beauchamp and Childress (2001), } \\
\text { Report from the Nuffield Council on } \\
\text { Bioethics (2020) }\end{array}$ \\
\hline
\end{tabular}

Short case studies are provided as example of each challenge from Chilean legislation

\section{Human-derived product manufacturing}

There are several steps that a developing country must adopt to offer high quality standard grafts, in a sustainable, quality industrialized tissue services. Firstly, four relevant bioethics principles must always be considered (Beauchamp and Childress 2001; Council of Europe 2018; Erk 2012; Report from the Nuffield Council on Bioethics 2020; see Footnote 2) (Table 1). Then, there are critical steps needed for high quality graft manufacturing (Fig. 1) including: the recruiting, consenting, evaluating and examining the donor in order to continue with the processing, storage and distribution of the tissue (European Directorate for the Quality of Medicines \& Healthcare (EDQM) 2019). There are two types of donors: (I.) the cadaveric donor (CD) with consent for the use of their body for the treatment of others. This type allows tissues such as bones, heart valves, skin, corneas, ligaments, cartilages and nerves to be used for therapeutic purposes (European Directorate for the Quality of Medicines \& Healthcare (EDQM) 2019; Saegeman et al. 2009). (II.) The living donors (LD) can donate several tissues too. In this case different consideration of decreasing donor morbidity must be taken into account, such as perinatal tissue (Witkowska-Zimny and Wrobel 2011; Koizumi et al. 2000) (e.g. amniotic membrane, placenta and umbilical cord-derived hematopoietic stem cells), hematopoietic stem cells (Weissman and Shizuru 2008) and bones from femoral heads that are removed during a hip replacement (Lomas et al. 2013), among others (Table 2). To enhance donation, it is recommended that any potential organ donor be referred to the local procurement unit and that all deaths (usually hospital deaths) should be processed with a 


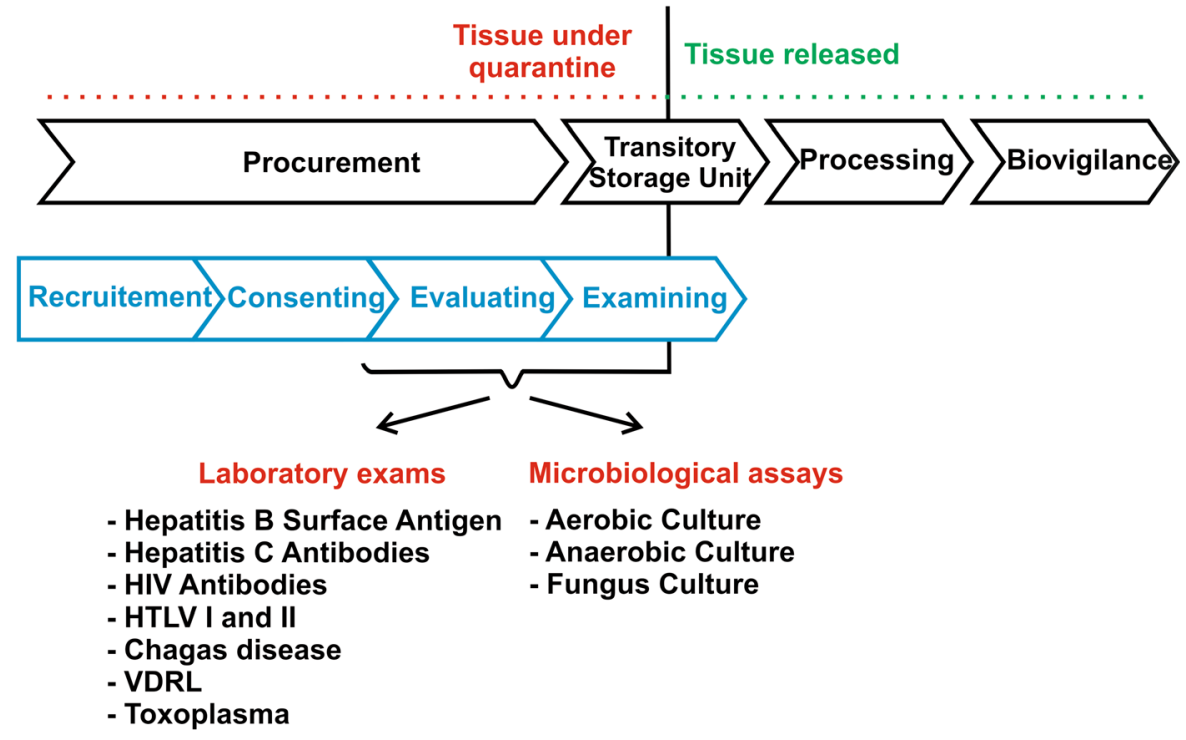

Fig. 1 Tissue manufacturing process. To obtain safe tissue grafts, the procurement team is responsible for several tasks depending on local hospital logistics; usually they conduct the donor's recruitment, informed consent, clinical history evaluation and donor testing. Harvested tissues remain under quarantine until all test results come back negative and the

procurement coordinator, regardless of the patient's age, the cause of death, or known diseases (European Directorate for the Quality of Medicines \& Healthcare (EDQM) 2019). After the identification, the informed consent of the donor must be obtained in a documented way through their family declaration in the case of the $\mathrm{CD}$, and with the deceased donor with brain death (DBD), a process known in Chile as "Last will testimony request", which is carried out by trained personnel of the procurement unit (Ministerio de Salud 2018).

During the screening stage, the anamnesis process, performed by the members of the procurement team, is essential to gather the clinical history and behaviour of the potential donor and detailed clinical data revision should be performed for any $\mathrm{LD}, \mathrm{CD}$ or DBD (Ministerio de Salud 2018). This selection phase is very effective in preventing disease transmission; it is estimated that after the pre-selection of the clinical and behavioural history, the risk of a donor being positive for pathogens detection during the second phase (haematological tests), is less than 1 in 1500 (Lomas et al. 2013). If any potential donor meets the criteria, they will proceed with the microbiological and serological laboratory tests (Fig. 1). The "quarantine" tissue can proceed with the processing. For this, general laboratory, microbiological and serological tests are performed according to Chilean Technical Standard No. 200 (Ministerio de Salud 2018). After implantation, all tissues must undergo an established follow up, commonly known as bio-vigilance period

(i.e. a period in which the extracted tissues are stored and isolated) is the time when the results of the exams are pending, and, therefore, no decision has been made whether the tissue will be processed and used as grafts or will be discarded. These exams are widely known and standardized, but the local epidemiological scenario for each developing country could vary, especially considering some local diseases present. For example, "Chagas disease" is a specific infectious disease caused by the Trypanosoma cruzi parasite and it is found in Mexico, Central and South America (Maya et al. 2010). In Chile, the quarantine is carried out in the "Transitory Storage Units (UATs)" that have all the infrastructure requirements and technical conditions for adequate tissue preservation; (Ministerio de Salud 2018) such as cryopreservation at $-80{ }^{\circ} \mathrm{C}$ for bone, skin and amniotic membrane (Ministerio de Salud 2018) and at $-140^{\circ} \mathrm{C}$ for cardiovascular tissue by special equipment qualified for containing liquid nitrogen (European Directorate for the Quality of Medicines \& Healthcare (EDQM) 2019). It is a feasible option to initially start with $-80{ }^{\circ} \mathrm{C}$ cryopreservation in transfusion medicine units or blood banks while waiting for the infrastructure development of controlled environments at tissue 
Table 2 Most used tissues and their benefits for the transplant recipient Reproduced with permission from "GUIDE TO QUALITY AND SAFETY OF TISSUES AND CELLS FOR HUMAN APPLICATION 4th Edition 2019" (European Directorate for the Quality of Medicines \& Healthcare (EDQM) 2019)

\begin{tabular}{|c|c|c|}
\hline Tissue & Function & Benefits for recipients \\
\hline $\begin{array}{l}\text { Amniotic } \\
\text { membrane }\end{array}$ & $\begin{array}{l}\text { It forms the amniotic sac, filled with amniotic fluid that } \\
\text { surrounds and protects the foetus; transfers oxygen and } \\
\text { nutrients from the mother to the foetus }\end{array}$ & $\begin{array}{l}\text { Used in burns and wound healing (to reduce surface } \\
\text { inflammation, scarring, and pain in surgical } \\
\text { applications), in certain types of ulcers, and in oral, } \\
\text { maxillofacial, and ocular surface surgery }\end{array}$ \\
\hline $\begin{array}{l}\text { Bone and } \\
\text { cartilage }\end{array}$ & Supports the body and protects vital organs & $\begin{array}{l}\text { It is used to repair or stabilize the spine and other bones } \\
\text { and cartilage damaged by degeneration, trauma, cancer, } \\
\text { or birth defects. It is also used in oral surgery and in the } \\
\text { filling of bone cavities or other areas where bone mass } \\
\text { has been lost }\end{array}$ \\
\hline Corneas & $\begin{array}{l}\text { The cornea and sclera form the outer layer of the eye: the } \\
\text { cornea is transparent and allows light pass into the eye; } \\
\text { the white sclera is opaque }\end{array}$ & $\begin{array}{l}\text { Indicated for visual problems caused by damage or } \\
\text { deterioration of the front part of the eyeball. If whole } \\
\text { eyes are donated, the corneas can be used in transplants } \\
\text { for corneal blindness and the sclera can be used for } \\
\text { reconstructive and glaucoma surgery }\end{array}$ \\
\hline $\begin{array}{r}\text { Cardiac } \\
\text { valves }\end{array}$ & Directs blood flow in the heart & $\begin{array}{l}\text { Used for patients with valve defects, especially in } \\
\text { children }\end{array}$ \\
\hline Pericardium & Forms a protective lining around the heart & $\begin{array}{l}\text { It is used to replace the dura in the brain and for eye and } \\
\text { dental/maxillofacial surgeries (e.g. alveolar ridge } \\
\text { augmentation) }\end{array}$ \\
\hline Skin & $\begin{array}{l}\text { Protects the body against injury, infection and } \\
\text { dehydration }\end{array}$ & $\begin{array}{l}\text { Used for the treatment of patients with burns, certain } \\
\text { types of ulcers, abdominal wall repairs, and } \\
\text { reconstructive and plastic surgery }\end{array}$ \\
\hline Tendons & Attach the muscle to the bone & For use in joint injuries and tendon ruptures \\
\hline $\begin{array}{r}\text { Vein and } \\
\text { arteries }\end{array}$ & Provide a structure for blood flow through the body & $\begin{array}{l}\text { It replaces blood vessels that are damaged by illness, } \\
\text { trauma, or prolonged dialysis treatment. It is also used } \\
\text { in bypass surgery to redirect blood flow }\end{array}$ \\
\hline
\end{tabular}

banks. For example, this process has already been implemented by the CNPT as a strategic development plan and there are several UATs in addition to the SNSS that can be used as a step towards further sustainable transplantation service buildout.

It should be mentioned that despite the exactness of the serological tests, there will be a period in which the pathogen present in the donor population will be undetectable; (Suessner et al. 2014) for example, during the incubation period of Human Immunodeficiency Virus (HIV) and Hepatitis C virus. To improve tissue transplant safety, the procurement continues with processing and sterilization, in order to reduce the risk of pathogen transmission, both known and unknown. Processing refers to all operations involved in the preparation, handling, preservation, packaging and microorganism's inactivation in tissue or cell donations intended for human application in order to optimize their clinical use, and preservation of original physicochemical and biological properties, for the reduction of disease transmission and adverse effects, such as the auto-immune reactions (European Directorate for the Quality of Medicines \& Healthcare (EDQM) 2019). This processing must be carried out according to standards of good manufacturing practices (GMP) in authorized, validated "clean-rooms", in closed spaces, where air particles and pollutants are kept within strict limits under continuous monitoring (European Directorate for the Quality of Medicines \& Healthcare (EDQM) 2019). These rooms must demonstrate a sterile process and be equivalent to Grade A with a recommended environment of $\mathrm{B}$, but at least Grade D in the case of transplant tissue (Directive 2006; EudraLex 2008). The main processing procedures (European Directorate for the Quality of Medicines \& Healthcare (EDQM) 2019) include cleaning, cutting, washing, milling, centrifuging, bathing in antibiotic solution, filtration, lyophilization, 
freezing, glycerolization, demineralization, decellularization (Crapo et al. 2011) and sterilization (Taylor 1999; Anderson et al. 1992; Pelker et al. 1983), all of which need to be implemented under stringent clean room rules and validated methods.

Sterilization procedure refers to any process that eliminates or deactivates transmissible infectious agents that contain nucleic acids (Calvo et al. 2011), either vegetative forms or spores of bacteria and fungi, parasites and viruses. The level of sterility assurance (SAL) is the likelihood of viable microorganisms in a unit of product after sterilization and is described by SAL $10^{-6}$ that would ensure that less than one in every million contaminants would survive in the sterilized graft. ${ }^{3}$ The most common methodology for terminal allograft sterilization is gamma irradiation (Hamer et al. 1999; Akkus et al. 2005; Dziedzic-Goclawska et al. 2005) using 25 kilograys (kGy) and can be applied after any processing, allowing sealing in its final packaging. In Chile, as well as many other developing countries, under the technical assistance program of the International Atomic Energy Agency (IAEA) (Morales-Pedraza and Phillips 2009), this service can be requested from any local procurement unit through the national centralized coordination managed by the CNPT with the "National Tissue Bank". Here the tissue is processed for later irradiation in an agreement with the "Chilean Nuclear Energy Commission" (Ministerio de Salud 2018; Tallentire 1990), which has been a successful partnership after Chile joined the Latin American Association of Tissue Banks (ALABAT) around the year 2002 (Morales Pedraza et al. 2011). However, this sterilization technique cannot be applied to all tissues, e.g. cardiovascular tissue, due to direct damage to the biological structure (Yusof 2001), it is not recommended for bone grafts (Fawzi-Grancher et al. 2009; Kluger et al. 2003; Moreau et al. 2000; Nguyen et al. 2007; Ijiri et al. 1994) due to collagen degradation at $25 \mathrm{kGy}$ that may cause lower remodelling and angiogenesis capacity, among others, and gamma-irradiation it is not capable of removing prions, which can be the cause of Creutzfeldt-Jakob disease (Lomas et al.

\footnotetext{
3 Submission and Review of Sterility Information in Premarket Notification $(510(\mathrm{k}))$ Submissions for Devices Labeled as Sterile Guidance for Industry and Food and Drug Administration Staff Document issued on 21 Jan 2016. https://www.fda. gov/media/74445/download. Accessed on May 2020.
}

2013). To solve the ultrastructure disruption drawback, tissue banks have implemented several other techniques, such as electron beam irradiation (Keshlaf and Schmidt 2011), and peracetic acid treatment for bone sterilization that has demonstrated to be a reliable method for sterilization of tissues grafts (Mahirogullari et al. 2007; Pruss et al. 2003).

\section{Quality management system}

To guarantee the bioethics principle "non-maleficence" or any harm for the recipient, the risk of tissue transplantation should be minimized to the greatest extent and be addressed with planned quality standards in order to deliver a product according to expectations and affordable costs (i.e. with established quality, safety and effectiveness). Quality management consists in a series of acts of supervising all the necessary activities under rigorous control and monitoring system, so that the product has the capacity to meet the specific clinical needs (Pharmaceutical Quality System 2020). This is performed through "knowledge management", a systematic approach to acquire, analyse, store and deliver information on the products, manufacturing processes and components of the tissue bank. It must be applied to all critical points of the process, such as human resources, facilities, equipment, suppliers and/or consumables. One of its major components is "risk management", or a proactive approach to identify, scientifically assess and control potential risks to quality and processes. This can be accomplished by analysing the graft during manufacturing operations with emphasis on its critical stages to allow state control that facilitates continuous process improvement. Also, this management should enable the implementation of corrections and changes. In the case of possible adverse reactions investigated in the bio-surveillance (Ministerio de Salud 2018), post-graft quality monitoring or other detailed postaudit/inspections are used. The documentation must assure that all tissue-related data can be verified and tracked, both by the donor and the recipient. Since the 1990s several developing countries from Asia, the Pacific and Latin America have joined professional associations for the promotion of tissue banking activities (e.g. ALABAT) (Morales Pedraza et al. 2011). In Chile, this is evidenced by efforts in the traceability made through the National Transplant 
Coordination (CNPT) that provides local procurement units with the Integrated Donation and Transplant System (SIDOT). This data management system was implemented in the 2014 and was created based on the original Spanish system, one of the pioneers in procurement and transplantation worldwide. After some time of use, the system was completely modified and adapted to the local needs and currently presents considerable improvements compared to its initial version. The current model complies with international standards and operates in real time alongside with the waiting lists administered by the local health authority the "Institute of Public Health" (ISP), which allows the monitoring of organ and tissue transplants. Another important pillar of this quality system consist of the scheduled internal (e.g. quality personnel) and external audits (e.g. accreditation entities) by independent bodies for certification (i.e. authorizations in Chile). This ensures accreditation is kept up to date and continuous improvements are made.

Validation is the part of the quality management system, which demonstrates that all critical aspects of operations are controlled to deliver a safe graft, in a continuous and adequate manner for its purpose (EudraLex - Volume 2015; Smith et al. 2015; Guideline 1995) (Fig. 2). Validation must be planned and can only be carried out and documented by trained personnel through a "master validation plan". Initially a "qualification" is made to each part of the process and to individual elements that include clean room facilities, equipment, computer systems, materials (i.e. consumables) and operations. Then, when the critical stages are identified after a risk analysis, the validation of the graft production process is executed with the aim of establishing that all the quality attributes and process parameters can be consistently fulfilled. The validation is then carried out after the qualification of all the elements used (e.g. analytical instruments or cleaning procedures), before starting a new process [e.g. decellularized bone scaffold (Smith et al. 2015)] and before any tissue product is released (prospective validation).

Risk management refers to the systematic processes designed to coordinate, facilitate and improve decision making, based on scientific evidence regarding the risk for graft quality during its life cycle (Fig. 2) (Quality Risk Management 2005). The level of effort and documentation of the quality risk management process must be proportional to the risk for the recipient. A "process flow" diagram that lists all the steps, processes, consumables, tests and equipment related to the specific graft can form the basis for the evaluation exercise. This allows identifying risks, their probability of occurrence and their severity. All of which is key information for the decision making of preventive activities for risk reduction or acceptance. An acceptance of risk could vary on case by case by analysis of the balance between risks and benefits. For example, there is an established high public demand for bone graft in Chile, which could favour the use of fresh-frozen graft from femoral heads after hip replacement surgeries to increase hospital supply, an accepted risk that has proven to be safe over time in several scientific publications (Slooff et al. 1984; Schreurs et al. 2009; Dennis 2003). Effective risk management must guarantee the quality of the graft, as it provides a proactive means to identify and control possible problems during manufacturing chain and the chance for continuing improvement.

\section{Discussion and conclusions}

Worldwide, tissue transplantation employs various technologies that allowed a great improvement in the last 50 years, such as the application of cryopreservation to ensure the continuous supply of grafts (Polge et al. 1949; Pegg 1976; Bozic and Marjoua 2012), which was later complemented by the quality management systems that induced a positive impact on developed countries healthcare systems (Bozic and Marjoua 2012). In the case of developing countries that had initiated tissue transplant developmental measures (e.g. participation through the IAEA), regulatory improvements along with quality management systems, comparable to pharmaceutical regulations, must be established to lead to a funding of specialized infrastructure, industrial processes and human resources with high standard training (e.g. the use of cleanrooms for the control of air particles requires the support of quality systems, validation and risk management by trained and continuous training of personnel) (Warwick et al. 2009). To facilitate this development, the association with institutions that are experts in the field, such as the European Association of Tissue and Cell Banks (EATCB) must be made. Developing countries are in a position where lessons learned from such abovementioned associations can 


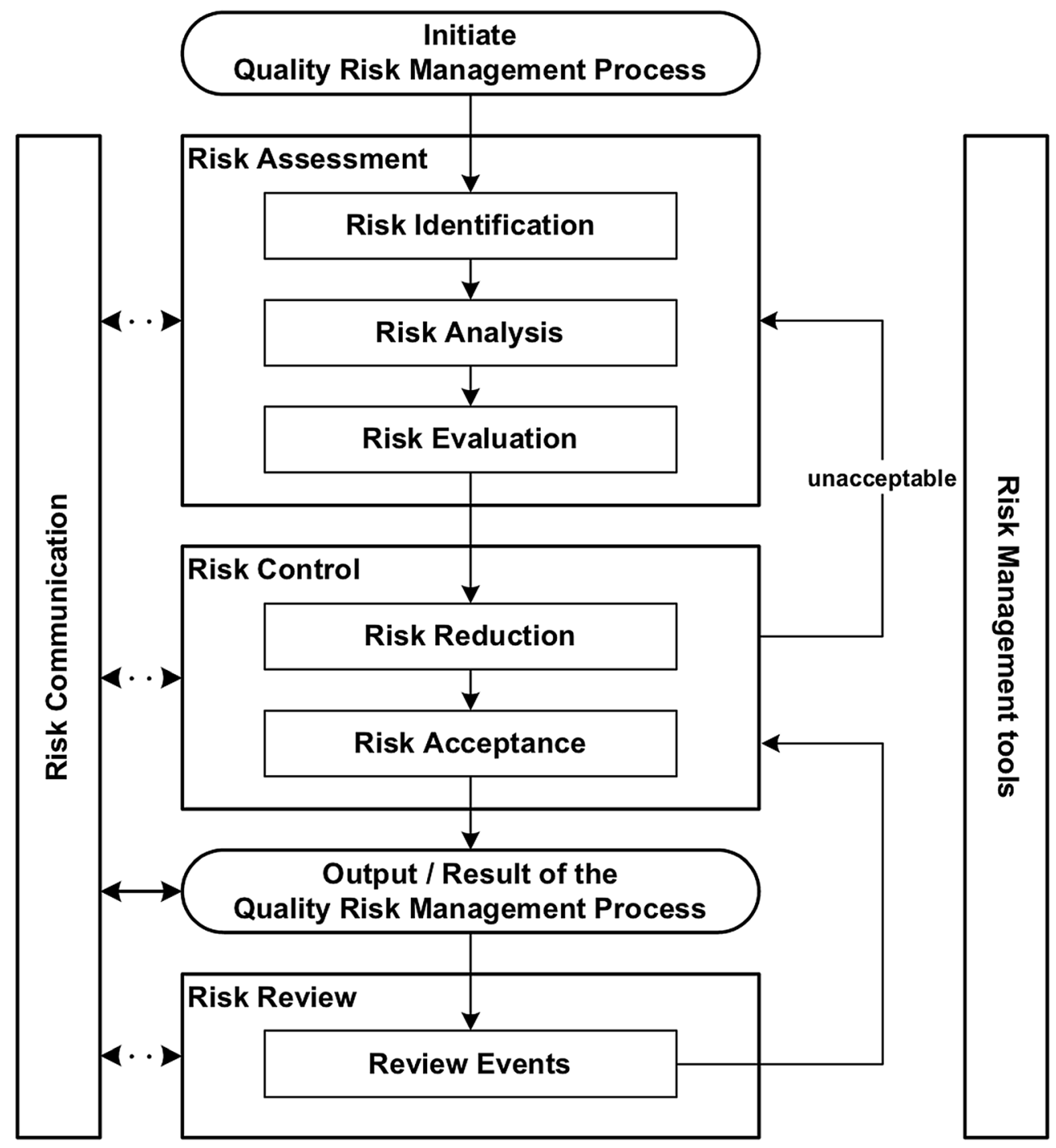

Fig. 2 Diagram of a quality risk management model. The emphasis is outlined on the strength that the risk management process must have throughout the graft production cycle, where consideration of all the elements will be incorporated at a level

be drawn for the introduction of novel processes and new clinical applications. This has been estimated in the EU to be clinically-driven with the involvement and cooperation of three main groups: tissue establishments, clinicians and risk analysis made by local health authorities, creating a constant interaction between all parties involved (European Directorate for the Quality of Medicines \& Healthcare (EDQM) 2019). Developing countries can benefit from lessons of detail that is proportional to the specific risk Reproduced with permission (Yusof 2001). Copyright 2015, (C) European Medicines Agency

learned from these associations from the EU, as they can facilitate the supply of the production-training ecosystem and participate in several events, where the state-of-the-art is exposed to an efficient life-cycle management, as they have experienced several years in process validation, risk prevention and continuous improvement systems. In particular, the training programs of "The International Council for Harmonization of Technical Requirements for 
Pharmaceuticals for Human Use (ICH) ${ }^{" 4}$ in relation to quality management concepts are required.

Accordingly to the United Nations, sustainable development goal N.17 "strengthen the means of implementation and revitalize the global partnership for sustainable development", association of health services with academia generates multidisciplinary clusters for the generation of innovation that deliver value and can deliver new, more advanced biotechnological products, spin-offs and start-ups, leading to more translational research and development projects (Casanellas et al. 2019; Couto et al. 2019; Cazzell et al. 2017; Boráň et al. 2017). To highlight these, clearly academia has been the major stakeholder for the technological development from cell transplantation. This led to the appearance of the advanced therapy medicinal products (ATMPs) industry, a core industry developing human-derived tissue products disruptive innovations, originating from academic environments (Advanced Therapies Investment Report 2017). This has been achieved due the increased inter-sectorial alliances, such as industry-academia, research collaborations and partnerships. Example of such recent great novel development case is "chimeric antigen receptor T cells (CAR-Ts) (Seimetz et al. 2019). In the $\mathrm{EU}$, in 2012, there were 18 ATMPs authorised for manufacture and supply under hospital exceptions, the majority developed through academic institutions. ${ }^{5}$ The global innovation eco-system is now needed more than ever, in light of the possible pandemics, ensuring the steady global knowledge-flow, but at the same time national sustainability in the case of an emergency.

The long-term sustainability of a tissue banking activity presents associated economic challenges, such as with the concept of human tissues that must remain without aims of financial gain (Council of Europe 2018) The Nuffield Council on Bioethics (Report from the Nuffield Council on Bioethics 2020) distinguished two types of interventions to improve donations, the abovementioned altruistic that should be the only

\footnotetext{
${ }^{4}$ The International Council for Harmonisation of Technical Requirements for Pharmaceuticals for Human Use (ICH). www. ich.org. Accessed on May 2020.

5 European Commission Pharmaceutical Committee. Hospital exemption for ATMPs (implementation of Art 28(2) of Regulation 1394/2007): update on feedback received by the Commission.).
}

ethical basis for donation and non-altruistic which they may be incentivised with payments options, but this has been suggested not to be encouraged (European Directorate for the Quality of Medicines \& Healthcare (EDQM) 2019). We exposed the case study from Chile, like any other state its health authority (i.e. MINSAL) is in charge of exercising the direction of the healthcare sector establishing the policies, plans and norms related to the tissue transplantation. Today, great normative efforts have been implemented with the technical standard $\mathrm{N}^{\circ} 200$ (Ministerio de Salud 2018) that specifies its rationale and how the donations should be conducted; therefore any health authority from developing countries, such as MINSAL, could define priorities for the allocation of budgets supported by cost studies with strong clinical outcome data (e.g. from the "Fondo Nacional de Salud" (FONASA) database) for the resolution of problems with graft requirements. These clinical data and studies would justify the generation of a potential extraordinary budget allocation added to the annual base provision for the resolution of priority problems that require specific investments (Becerril-Montekio et al. 2010). In another example, the implementation of cleanrooms could be justified by the need to generate greater productive capacity of grafts, in terms of volume and types in order to increase access and efficacy, respectively, but as well ensuring safe space for future healthcare endeavours. When the donation and transplantation of tissue is promoted locally as a developmental strategy, the resources will be used in a better way, since the associated costs actually only relate to the processing and storage service. In addition, if the healthcare system encourages this area, the costs of input suppliers will decrease and the associated complications and costs of auto-grafting will be reduced (e.g. donor site morbidity, hospital length-stays and out-of-pocket expenses). These last strategy in developing countries with public-private dual healthcare systems would contribute to health justice (Erk 2012) and universal access by avoiding health inequities based on these inputs, since it will limit the out-of-pocket expenses of patients outside the health explicit guaranties coverage (e.g. in Chile most known as GES-AUGE pathologies) or outside of insurance institutions, either public or private, and reducing the financial risk of healthcare users (Gallegos and Muñoz 2018). 
It is highlighted that for developing countries, the quality management concepts and validation and risk management must be understood, adopted and employed (World Health Organization 2006) to be able to implement cleanrooms according to tissue establishments developed-countries health authorities (COMMISSION DIRECTIVE 2003/94/EC 2003), which also lead to the challenge of the supervision and control capacity by the authorities from developing countries. In Chile, the ISP is in charge of supervising tissue establishments and banks of the healthcare system and everything related to the authorization, quality control, surveillance and importing of cells and tissues. However, it is the MINSAL who through the ISP service must direct biotechnological/biomedicine development according to health policies based on national reality and epidemiology with data-driven priority setting process. Tissue transplantation could be evaluated through "management commitments" of health services, which would later be evaluated by any division in charge of the healthcare network and be enhanced through financial stimuli associated with performance. For example, the ISP from Chile can enhance this development through activity plans in conjunction with tissue banks. Finally, the governmental, clinical and academic sectors have the responsibility of this development in order to achieve compliance with international quality and excellence standards. In the EU this has been established as a "dialogue structure" between the health authorities, clinicians and the tissue establishments (European Directorate for the Quality of Medicines \& Healthcare (EDQM) 2019). Tissues and cells as scientific area can be assumed as a beneficence for healthcare users (i.e. patients) as they are highly demanded for universal coverage and, at the same time, a necessity for future sustainable health systems development.

After reviewing the last years of a developing country case study example, such as Chile with its tissue transplants services implementation and taking into account the standards of tissue services from several developed countries from the EU, we propose a summary of concepts that developing nations should address in order to implement sustainable tissue services:

- Update and/or establish detailed regulatory framework, both global and local norms and laws for comparisons and buildout strategies, the WHO guidelines could be considered the backbone of them. The relationship and effective communication between clinicians and health authorities is vital. In case of aiming to develop more advanced processing techniques, it is also required to examine developed countries advanced therapies medicinal products regulatory agenda for more technically complex novel tissue or cell grafts preparations, such as decellularization process leading to extracellular matrix scaffolds, cardiovascular tissues storage by liquid nitrogen, and stem cell transplantation and cellular therapy, among others.

- Be involved with international associations that intend to promote tissue transplantation worldwide, either directly through regional associations (e.g. American Association of Tissue Banks, AsiaPacific Association of Surgical Tissue Banking and Latin American Association of Tissue Bank, among others), or indirectly, such as the EATCB, the European Directorate for the Quality of Medicines and Healthcare and the ICH. This should ensure knowledge crucial for professional's certification for implementing high standards safety and quality processes and for acquiring novel skills for cell and tissue human-derived product development.

- Creation of inter-sectorial alliances for mutual goal endeavours in the healthcare services. The communication flow is encouraged between main parties (i.e. clinicians, tissue establishments and health authorities) under a life-cycle management comprising alliance to face the implementation of state-of-the-art knowledge exchange. Additionally, new biotechnologies that can facilitate novel tissue-associated product and services are needed, and the health sector must be involved with academic and research institutions that can employ tissues for research, development and innovation. This will ensure smooth knowledge transfer and generate new value for patients.

- Regularly assess tissue transplant-activity related data to ensure appropriate actions are taken. With more complete set of data better benefit-risk ratio can be obtained. By analysing epidemiology, demand and clinical outcome data of grafts and transplantation (e.g. which grafts are demanded?, which grafts represent higher hospital costs?), 
better evidenced-based decisions can be designed. These reports will aid authorities with better funds allocation, leading to more resources \& knowledge-based decisions.

Acknowledgements Special thanks to all members of the team involved in the project from the Hospital Traumatológico de Concepción, Transfusion Medicine Unit and Procurement Unit from Hospital Clínico Regional, Dr. Guillermo Grant Benavente and the Servicio Salud Concepción for the guidance.

Author contributions FJV-A: Conceptualization; FJV-A: Methodology; FJV-A, JKW: Validation; FJV-A: Investigation; FJV-A, JKW: Writing-original draft preparation; FJV-A, JKW, MJ, SJ, SG: Writing-review and editing; FJV-A, JKW: Visualization; FJV-A, JKW, SG: Supervision; FJV-A: Project administration; FJV-A, JKW: Funding acquisition.

Funding The authors would like to acknowledge funding from Corporación de Fomento de la Producción de Chile (CORFO, grant number 18IIP-BB-99543) and the Royal Society of Chemistry (M19-6613).

\section{Compliance with ethical standards}

Conflict of interest The authors declare no conflict of interest.

\section{References}

Acarturk TO, Hollinger JO (2006) Commercially available demineralized bone matrix compositions to regenerate calvarial critical-sized bone defects. Plast Reconstr Surg 15(118):862-873

Additional Protocol to the Convention on Human Rights and Biomedicine concerning Transplantation of Organs and Tissues of Human Origin. ETS 186-Human Rights and Biomedicine (Additional Protocol), Strasbourg, 24.I.2002. https://rm.coe.int/CoERMPublicCommonSearchServices/ DisplayDCTMContent?documentId=0900001680081562. Visited on May 2020

Advanced Therapies Investment Report (2017) The challenges and opportunities of the advanced therapy sector. A guide to successful investment. Produced by Phacilitate. https:// www.phacilitate.co.uk/sites/default/files/clarion_ phacilitate/pdfs/advanced_therapies_investment_report_ phacilitate.pdf. Accessed on October 2020

Akkus O, Belaney RM, Das P (2005) Free radical scavenging alleviates the biomechanical impairment of gamma radiation sterilized bone tissue. J Orthop Res 23:838-845

Allegrini S Jr, Koening B Jr, Allegrini MR, Yoshimoto M, Gedrange T, Fanghaenel J et al (2008) Alveolar ridge sockets preservation with bone grafting-review. Ann Acad Med Stetin 54:70-81

Anderson M, Keyak J, Skinner H (1992) Compressive mechanical properties of human cancellous bone after gamma irradiation. J Bone Joint Surg Am 74:747-752
Ashammakhi N, Ahadian S, Darabi MA, El Tahchi M, Lee J, Suthiwanich K et al (2019) Minimally invasive and regenerative therapeutics. Adv Mater 31(1):e1804041

Badylak SF, Taylor D, Uygun K (2011) Whole-organ tissue engineering: decellularization and recellularization of three-dimensional matrix scaffolds. Annu Rev Biomed Eng 13:27-53

Beauchamp TL, Childress JF (2001) Principles of biomedical ethics, 5th edn. Oxford University Press, New York

Becerril-Montekio V, Reyes J, Manuel A (2010) Sistema de Salud de Chile. Salud publica de México 53:s132-s142

Benninger E, Zingg PO, Kamath AF, Dora C (2014) Cost analysis of fresh-frozen femoral head allografts: is it worthwhile to run a bone bank? Bone Joint J 96-B:1307-1311

Boráň T, Menezes-Ferreira M, Reischl I, Celis P, Ferry N, Gänsbacher B et al (2017) Clinical development and commercialization of advanced therapy medicinal products in the european union: how are the product pipeline and regulatory framework evolving? Hum Gene Ther Clin Dev 28:126-135

Bozic K, Marjoua Y (2012) Brief history of quality movement in US healthcare. Curr Rev Musculoskelet Med 5:265-273

Calota DR, Nitescu C, Florescu IP, Lascar I (2012) Surgical management of extensive burns treatment using allografts. J Med Life 5:486-490

Calvo R, Figueroa D, Días-Ledezma C, Vaisman A, Figueroa A (2011) Aloinjertos óseos y la función del banco de huesos. Rev Med Chile 139:660-666

Campana V, Milano G, Pagano E, Barba M, Cicione C, Salonna $G$ et al (2014) Bone substitutes in orthopaedic surgery: from basic science to clinical practice. J Mater Sci Mater Med 25:2445-2461

Canzi G, Talamonti G, Mazzoleni F, Bozzetti A, Sozzi D (2018) Homologous banked bone grafts for the reconstruction of large cranial defects in pediatric patients. J Craniofac Surg 29:2038-2042

Casanellas I, Lagunas A, Vida Y, Pérez-Inestrosa E, Andrades JA, Becerra J et al (2019) Matrix nanopatterning regulates mesenchymal differentiation through focal adhesion size and distribution according to cell fate. Biomimetics (Basel) $4: 43$

Cazzell S, Vayser D, Pham H, Walters J, Reyzelman A, Samsell B et al (2017) A randomized clinical trial of a human acellular dermal matrix demonstrated superior healing rates for chronic diabetic foot ulcers over conventional care and an active acellular dermal matrix comparator. Wound Repair Regen 25:483-497

Chau AM, Xu LL, Wong JH, Mobbs RJ (2014) Current status of bone graft options for anterior interbody fusión of the cervical and lumbar spine. Neurosurg Rev 37:23-37

Code of Federal Regulations Title 21 (2020) Human cells, tissues, and cellular and tissue-based products, Code of Federal Regulations Title 21, United States Food and Drug Administration. Website: https://www.accessdata.fda.gov/ scripts/cdrh/cfdocs/cfcfr/CFRSearch.cfm?CFRPart=1271. Accessed on May 2020

COMMISSION DIRECTIVE 2003/94/EC (2003) Laying down the principles and guidelines of good manufacturing practice in respect of medicinal products for human use and investigational medicinal products for human use. Official 
Journal of the European Union. https://eur-lex.europa.eu/ LexUriServ/LexUriServ.do?uri=OJ:L:2003:262:0022: 0026:en:PDF. Accessed on May 2020

Competent Authorities on Substances of Human Origin Expert Group (CASoHO E01718) (2020) Meeting of the competent authorities for tissues and cells. Summary Minutes. https://ec.europa.eu/health/sites/health/files/blood tissues_organs/docs/ev_20190513_sr_en.pdf. Accessed on May 2020

Council of Europe (2018) Guide for the implementation of the principle of prohibition of financial gain with respect to the human body and its parts from living or deceased donors. https://rm.coe.int/guide-financial-gain/16807bfc9a. Accessed 5 Dec 2018

Couto PS, Shatirishvili G, Bersenev A (2019) Verter F First decade of clinical trials and published studies with mesenchymal stromal cells from umbilical cord tissue. Regen Med 14:309-319

Crapo PM, Gilbert TW, Badylak SF (2011) An overview of tissue and whole organ decellularization processes. Biomaterials 32:3233-3243

Cuarto Informe y final FIC Regional (2013) Implementación de un banco de tejido óseo para la Región de Coquimbo. https://outlook.live.com/mail/search/id/AQQkADAwATYOMDABLTgzYjktOTkANTUALTAwAi0wMAoAEAB0bQ5vjydLhYZ5dKB2IXCs/sxs/ AQMkADAwATY0MDABLTgzYjktOTkANTUALTAwAi0wMAoARgAAA7gu3w\%2FcNUhIAKkv3MjKDWuuBwDHd\%2BWLTVShQpiTDyPu6N03AAACAQwAAADHd\%2BWLTVShQpiTDyPu6N03AAK9kW66AAAAARIAEADr92fNX1q9Tr6IdaJ5ihh7. Visited on May 2020

Decreto Exento 148 (2016) Ratifica resolución exenta $N^{\circ} 521$, de 11 de abril de 2014 y sustituye norma técnica $\mathrm{N}^{\circ} 163$, para procuramiento, preservación e implante de córnea. http:// normativas.minsal.cl/DECRETOS/decreto_ex_148_16_ spNGT_163_CORNEA.pdf. Accessed on May 2020

Decreto $\mathrm{N}^{\circ} 35$ (2013) APRUEBA REGLAMENTO DE LA LEY $\mathrm{N}^{\circ}$ 19.451, QUE ESTABLECE NORMAS SOBRE TRASPLANTE Y DONACIÓN DE ÓRGANOS. https:// www.leychile.cl/Navegar?idNorma $=1055362$. Accessed on May 2020

Dennis D (2003) Management of massive acetabular defects in revision total hip arthroplasty. J Arthroplasty 18:121-125

Directive 2006/86/EC as regards traceability requirements, notification of serious adverse reactions and events and certain technical requirements for the coding, processing, preservation, storage and distribution of human tissues and cells. https://eur-lex.europa.eu/LexUriServ/LexUriServ. do?uri=OJ:L:2006:294:0032:0050:EN:PDF, Accessed on May 2020

Drosos GI, Touzopoulos P, Ververidis A, Tilkeridis K, Kazakos $\mathrm{K}$ (2015) Use of demineralized bone matrix in the extremities. World J Orthop 18:269-277

Dziedzic-Goclawska A, Kaminski A, Uhrynowska-Tyszkiewicz I, Stachowicz W (2005) Irradiation as a safety procedure in tissue banking. Cell Tissue Bank 6:201-219

Erk C (2012) Just health (care): social justice, health and the common good. Zeitschrift für Wirtschafts- und Unternehmensethik 13:31-49
EudraLex (2008) EU guidelines for good manufacturing practices for medicinal products for human and veterinary use (GMP). Annex 1: Manufacturing of sterile medicinal products. Brussels

EudraLex - Volume 4 (2015) EU Guidelines for Good Manufacturing Practices for Medicinal products for Human and Veterinary Use. Brussels. https://eur-lex.europa.eu/legalcontent/EN/TXT/PDF/?uri=CELEX:32003L0094\&from= EN. Accessed on May 2020

European Commission Pharmaceutical Committee. Hospital exemption for ATMPs (implementation of Art 28(2) of Regulation 1394/2007): update on feedback received by the Commission.)

European Directorate for the Quality of Medicines \& Healthcare (EDQM) (2019) Guide to the quality and safety of tissues and cells for human application, 4th edn. Council of Europe, Strasbourg

Fawzi-Grancher S, Goebbels RM, Bigare E, Cornu O, Gianello P, Delloye C et al (2009) Human tissue allograft processing: impact on in vitro and in vivo biocompatibility. J Mater Sci Mater Med 20:1709-1720

Fratzl P (2007) Biomimetic materials research: What can we really learn from nature's structural materials? J R Soc Interface 4:637-642

Gallegos E, Muñoz A (2018) Protección financiera en salud: evolución y comparación del gasto de bolsillo de los hogares chilenos. Rev Med Chile 146:737-744

ICH Guideline (1995) International Conference on Harmonisation Q2 (R1) validation of analytical procedures: text and methodology. Current Step 5. https://www.ema.europa.eu/ en/documents/scientific-guideline/ich-q-2-r1-validationanalytical-procedures-text-methodology-step-5_en.pdf. Accessed on October 2020

Hamer AJ, Stockley I, Elson RA (1999) Changes in allograft bone irradiated at different temperatures. J Bone Joint Surg Br 81:342-344

Hospital Las Higueras implementó el primer Banco de Hueso de la Región del Biobío (2018). https://www.minsal.cl/ hospital-las-higueras-implemento-el-primer-banco-dehueso-de-la-region-del-biobio/. Visited on May 2020

Human Tissue (2020) The Human Tissue (Quality and Safety for Human Application) Regulations 2007. No. 1523. http://www.legislation.gov.uk/uksi/2007/1523/pdfs/uksi_ 20071523_en.pdf. Accessed on May 2020

Human Tissue Authority (2020) Guide to quality and safety assurance for human tissues and cells for patient treatment. https://www.hta.gov.uk/sites/default/files/HTA\% 20guide $\% 20$ to $\% 20$ Quality $\% 20$ and $\% 20$ Safety $\%$ 20Assurance $\% 20$ for $\% 20$ Human $\% 20$ Tissue $\% 20$ and $\%$ 20Cells \%20for\%20Patient $\% 20$ Treatment $\% 20 \mathrm{v} 2 \%$ 20April\%202018.pdf. Accessed on May 2020

Ijiri S, Yamamuro T, Nakamura T, Kotani S, Notoya K (1994) Effect of sterilization on bone morphogenetic protein. J Orthop Res 12:628-636

Kao ST, Scott DD (2007) A review of bone substitutes. Oral Maxillofac Surg Clin N Am 1(9):513-521

Keshlaf S, Schmidt T (2011) Fractionation of high-dose electron beam irradiation of BPTB grafts provides significantly improved viscoelastic and structural properties compared to standard gamma irradiation. Knee Surg Sports Traumatol Arthrosc 19(11):1955-1961 
Kluger R, Bouhon W, Freudenberger H, Kroner A, Engel A, Hoffmann O (2003) Removal of the surface layers of human cortical bone allografts restores in vitro osteoclast function reduced by processing and frozen storage. Bone 32:291-296

Koizumi NJ, Inatomi TJ, Sotozono CJ, Fullwood NJ, Quantock AJ, Kinoshita S (2000) Growth factor mRNA and protein in preserved human amniotic membrane. Curr Eye Res 20:173-177

Ley $\mathrm{N}^{\circ} 19.451$ (1996) ESTABLECE NORMAS SOBRE TRASPLANTE Y DONACION DE ORGANOS. http:// www.sml.gob.cl/transparencia/transparencia2009/ archivos_transparencia/marco/09.-LEY-19451_SOBRE\% 20TRANSPLANTES\%20Y\%20DONACI\%C3\%93N\% 20DE\%20ORGANOS.pdf. Accessed on May 2020

Lobb DC, DeGeorge BR Jr, Chhabra AB (2019) Bone graft substitutes: current concepts and future expectations. J Hand Surg Am 44:497-505

Lomas R, Chandrasekar A, Board TN (2013) Bone allograft in the U.K.: perceptions and realities. Hip Int 2:427-433

Mahirogullari M, Ferguson M, Whitlock PW (2007) Freezedried allografts for anterior cruciate ligament reconstruction. Clin Sports Med 26(1):625-637

Maya J, Orellana M, Ferreira J, Kemmerling U, López-Muñoz R, Morello A (2010) Chagas disease: present status of pathogenic mechanisms and chemotherapy. Biol Res 2010(43):323-331

Ministerio de Salud (2018) Norma general Técnica para el Procuramiento, Preservación e Implante de Tejidos. https://www.minsal.cl/wp-content/uploads/2018/03/NTde-Tejidos-Final.pdf. Visited on May 2020

Morales Pedraza J, Vajaradul Y, Alvarez I (2011) The future role of the professional associations in the promotion of tissue banking activities in Asia and the Pacific and in the Latin America regions. Cell Tissue Bank 12:319-327

Morales-Pedraza J, Phillips G (2009) The impact of the International Atomic Energy Agency (IAEA) program on radiation and tissue banking in Asia and the Pacific and the Latin American regions. Cell Tissue Bank 10(2):79-86

Moreau MF, Gallois Y, Basle MF, Chappard D (2000) Gamma irradiation of human bone allografts alters medullary lipids and releases toxic compounds for osteoblast-like cells. Biomaterials 21:369-376

Nguyen H, Morgan DA, Forwood MR (2007) Sterilization of allograft bone: effects of gamma irradiation on allograft biology and biomechanics. Cell Tissue Bank 8:93-105

Nkenke E, Stelzle F (2009) Clinical outcomes of sinus floor augmentation for implant placement using autogenous bone or bone substitutes: a systematic review. Clin Oral Implants Res 20:124-133

Pegg D (1976) Long-term preservation of cells and tissues: a review. J Clin Pathol 29:271-285

Pelker RR, Friedlander GE, Markham TC (1983) Biomechanical properties of bone allografts. Clin Orthop Relat Res 174:54-57

Pharmaceutical Quality System Q10 (2020) ICH Harmonised Tripartite Guidelines. In: International conference on harmonisation of technical requirements for registration of pharmaceuticals for human use. https://www.ema.europa. eu/en/documents/scientific-guideline/internationalconference-harmonisation-technical-requirements- registration-pharmaceuticals-human_en.pdf. Accessed on May 2020

Pierannunzi L, Zagra L (2016) Bone grafts, bone graft extenders, substitutes and enhancers for acetabular reconstruction in revision total hip arthroplasty. EFORT Open Rev $1: 431-439$

Polge C, Smith AU, Parkes AS (1949) Revival of spermatozoa after vitrification and dehydration at low temperatures. Nature 164:666

Pruss A, Göbel UB, Pauli G (2003) Peracetic acid-ethanol treatment of allogeneic avital bone tissue transplants a reliable sterilization method. Ann Transplant 8(2):34-42

Quality Risk Management Q9 (2005) ICH Harmonised Tripartite Guidelines. In: International conference on harmonisation of technical requirements for registration of pharmaceuticals for human use. Current Step 4. https:// database.ich.org/sites/default/files/Q9_Guideline.pdf. Accessed on May 2020

Report from the Nuffield Council on Bioethics (2020) Human bodies: donation for medicine and research. http:// nuffieldbioethics.org/?s=Human + bodies $\%$

$3 \mathrm{~A}+$ donation + for + medi- $\quad$ cine + and + research, Accessed on January 2020

Saegeman V, Verhaegen J, Lismont D et al (2009) Influence of post-mortem time on the outcome of blood cultures among cadaveric tissue donors. Eur J Clin Microbiol Infect Dis 28(2):161-168

Schreurs B, Keurentjes J, Gardeniers Verdonschot N, Slooff T, Veth R (2009) Acetabular revision with impacted morsellised cancellous bone grafting and a cemented acetabular component: a 20- to 25-year follow-up. J Bone Joint Surg Br 91:1148-1153

Seimetz D, Heller K, Richter J (2019) Approval of first CAR-Ts: have we solved all hurdles for ATMPs? Cell Med 11:2155179018822781

Slooff T, Huiskes R, van Horn J, Lemmens A (1984) Bone grafting in total hip replacement for acetabular protrusion. Acta Orthop Scand 55:593-596

Smith CA, Richardson SM, Eagle MJ, Rooney P, Board T, Hoyland JA (2015) The use of a novel bone allograft wash process to generate a biocompatible, mechanically stable and osteoinductive biological scaffold for use in bone tissue engineering. J Tissue Eng Regen Med. 9:595-604

Submission and Review of Sterility Information in Premarket Notification (510(k)) Submissions for Devices Labeled as Sterile Guidance for Industry and Food and Drug Administration Staff Document issued on 21 Jan 2016. https:// www.fda.gov/media/74445/download. Accessed on May 2020

Suessner S, Hennerbichler S, Schreiberhuber S, Stuebl D, Gabriel C (2014) Validation of an alternative microbiological method for tissue products. Cell Tissue Bank 15:277-286

Tallentire A (1990) Guidelines for industrial radiation sterilization of disposable medical products. IAEA-TECDOC539. International Atomic Energy Agency, Vienna, Austria

Taylor DM (1999) Inactivation of prions by physical and chemical means. J Hosp Infect 43:S69-S76 
The International Council for Harmonisation of Technical Requirements for Pharmaceuticals for Human Use (ICH). www.ich.org. Accessed on May 2020

Warwick R, Fehily D, Brubaker S, Eastlund T (2009) Tissue and cells donation: an essential guide. Wiley-Blackwell, Hoboken, NJ

Weissman I, Shizuru J (2008) The origins of the identification and isolation of hematopoietic stem cells, and their capability to induce donor-specific transplantation tolerance and treat autoimmune diseases. Blood 112(9):3543-3553

Witkowska-Zimny M, Wrobel E (2011) Perinatal sources of mesenchymal stem cells: Wharton's jelly, amnion and chorion. Cell Mol Biol Lett 16(3):493-514

World Health Organization (2006) Second global consultation on regulatory requirements for human cells and tissues for transplantation: towards global harmonization through graduated standards. World Health Organization, Geneva

World Health Organization (2010) Human organ and tissue transplantation. WHA63.22. The Sixty-third World Health
Assembly from the world Health Organization. https:// apps.who.int/gb/ebwha/pdf_files/WHA63/A63_R22-en. pdf?ua=1. Accessed on May 2020

World Health Organization (2020) WHO Guiding Principles on human cell, tissue and organ transplantation. World Health Organization. https://www.who.int/transplantation/ Guiding_PrinciplesTransplantation_WHA63.22en. pdf?ua=1. Accessed on May 2020

Yusof N (2001) Effect of radiation on microorganismsmechanism of radiation sterilisation. In: Nather A (ed) The scientific basis of tissue transplantation. World Scientific, Singapore, pp 342-357

Zorzi A, Miranda B (2012) Bone Grafting. eBooK. InTechOpen, Rijeka

Publisher's Note Springer Nature remains neutral with regard to jurisdictional claims in published maps and institutional affiliations. 